Vol. XXIII No 12017

\title{
DIPLOMACY AND SECURITY
}

\author{
Ștefan POP \\ “Nicolae Bălcescu” Land Forces Academy, Sibiu, Romania, \\ popstefan2000@gmail.com
}

\begin{abstract}
Changes in diplomacy are especially visible by the involvement of many new actors in the area of international cooperation. A fast developing international system opened doors to many new actors, including international organizations, transnational corporations, and important interest groups.Diplomacy that, from the middle of the 15th century, was known as an important tool of foreign policy became wider in the post-Cold War era. In fact, the transformation of diplomacy has not been completed yet. Nowadays, for instance, governmental diplomacy must deal with various nonstate actors that shape its agenda.
\end{abstract}

Keywords: diplomacy, security, external affairs

1. What is the diplomacy and when it appeared.

We can't speak about the diplomacy before the appearence of the state. Studying the documents which treat diplomacy history, we see that this history covers, in fact, the international relationships history. This confusion relies on the manner how lots of authors treat the evolution of statal exchanges in their works using the term of "history diplomacy" or " diplomatic history". If we try to comare international relationships history and diplomacy history, we understand that the former studies the appearance and development of the great internationat problems by making an analysis of their psychological sauses , interests and interactions.

\section{Definitions}

To better understand what the term of diplomacy covers, I will furthermore present several definitions given by the personalities who studied and worked with this throughout its history .

Here are some of these definitions:
Diplomacy, says Valeria Mohoc, acts as a mixture of gesture and words that a diplomat has in mind both addressed to influential person just to make him or her a successful one. [1]

According to Oxford Dictionary , diplomacy represents the leadership of international relationships by means of specific methods as well as negociations, all possible due to participations of ambassadorsand special sent national representatives. [2]

Diplomacy-familiar noun:

1. Activity done by the state workers as well as its abroad representatives or agencies meant to achieve the external political aims of a certain state.

2. Sometimes with a pejorative meaning: ability to behave in a diplomatic routine way. To this central ring one has to link lots of convergent threads, a whole and full of shades diplomacy . Galaction, O ,I 396 Our romanianwriter ,I.L.Caragiale mentions diplomacy in his literary works by saying : "One has to have a little diplomacy!" 
3. Career, working as a diplomat, job, diplomatic structure, Diplomatic as he was ,he could have enter diplomacy, too . [3].

Another Romanian,Cezar Petrescu, used the term of diplomacy as well: "I have some dresses for Sabina. Some diplomacy will be necessary to make her accept them". Cezar Petrescu. [4]

The Explicative Romanian Language Dictionary gives the following definition to diplomacy: All methods, means and activities used by a state in the field of international relationships in order to achieve its objectives and sins of external polities. Tact, ability, dexterity, elegancy, intelligence and wisdom. [5]

\section{Short history of diplomacy}

Appeared from Antiquity, diplomacy evaluated during history on different forms being determinated by the type of relationships among states. Speaking about diplomacy in its today forms, we have to underline that it appeared only in the XIVth century, after the neissance and spreading of the commercial and political international relationships due to the appearance of the first permanent diplomatic relationship.

Starting with the XIXth-XXth centuries, as a result of the international relationships, the diplomatic activity is no longer centered on cutumiar norms but it develop in respect of norms and principles of international law such as: respecting state sovereignity, refering norms to diplomatic imunities and priviligies, diplomatic levels and classes. this is the period when the achieving diplomacy form is different from the previous ones because it takes place under the shelter of diplomatic negociations, people use diplomatic correspondence while another important role is played by the participation at diplomatic conferences and congreses.

The appearance of the international organizations, those high leveled reunions inside these organizations and implications of the diplomatic missions, all contribute to the achievement of the understanding among world's states.

Speaking about achieving form, the diplomatic activity among different states is possible thriugh special national institutions created inside states just for their external relationships. This activity is done inside each state by the chief of the state, the government, the Ministry of External Affairs and outside it by the diplomatic missions, the commercial representatives and consulates.

As a consequence of mankind's evolution and the conflictual problems appeared in the middle of diplomatic relationships at on an international level, was born the necesity of creating some international institutions which should be able to ensure unique control and fair solving of all problems regarding relationships among states. For this purpose, each state must at national level an institution which could represent its interests. That's why The Diplomatic Service was created and it includes:

- The Ministry of External Affaires having the status of central institution;

- The Diplomatic Missions including the permanent representatives affiliated to the international organismes as well as on-thespot delegations and missions;

- The Consular Offices ;

- some other units created to facilitate the activity of the diplomatic services, here including, for example, the instruction and recycling process of all the necessary diplomatic staff.

The Ministry of External Affaires (M.E.A) [6] was created on $20^{\text {th }}$ of July 1862 , with the name of "The Ministry of Foreing Affaires" it's one of the ministries in romanian government. The name of Ministry of Foreing Affaires (MFA) was kept till the proclaiming if The Socialist Republic of Romania, when it was chamged into Ministry of External Affaires ( MEA) which is still avalaible nowadays. Source Wikipedia

The Ministry of External Affaires is responsible with the external polities of the Romanian State as well as with romanian 
status of member in the International Organisations. It also colaborates to the elaboration, fundamentation and achievement of the economical polities of Romania according to the legal rules and the governing programme.

Romania according to the legal rules and the governing programme.

\section{The External State Institutios for Diplomatic Relations}

Romania signed on $8^{\text {th }}$ of July 1968 The Convention regarding diplomatic relationships, convention resulted from The International Conference held in Viennes in 1961 under the patronage of the United Nations. The conventionon diplomatic relationships was signed by 63 states when held in Vienne and it became officially applied starting with $25^{\text {th }}$ April 1965. The Vienne Convention took into consideration the fundamental principles of states sovereignity, their rights equality and established the basis if developing diplomatic relationships and missions, exchanges only by respecting the mutual consignment of acreditant and acreditor states subject of the diplomatic reports, so that diplomatic missions, must exercise an active role in consolidating and developing international relationships, just by doing functins of reoresanting the acreditant state by protecting its interests, its citiens interests and those if the acreditar state as well. [7]

It also has to exercise:

- the negociating function with the government of this state

- the informing role by legal strategies; about the conditions and the events evolution from the acreditor state and, not last of all, to promote friendship reports to develop economical, cultural and scientifical relationships between those two states (art.3)

Throught art 4-7, The Convention also specifies the nominating procedure for the head of the diplomatic misssions throught art 8. , the citizenship of diplomatic staff at $13^{\text {th }}$ article, the starting moment of the functional diplomatic representative while at art.14-17 classes of head missions are specified.

In order to achieve eficiently the diplomatic functions, the Conventions establishes imunities and priviligies focused on the diplomatic missions as well as those to be enjoyed by the members of the missions staffs, respectively, their families.

Throught art 21,25 and 26 the Convention underlines the duties of the diplomatic mission towards the acreditar state essentialy fosusing on respecting lawes, not involving into internal affaires of the states. In a corelative way The Convention specifies the duty that acreditar state has to do all its best to fullfill the mission functions.

At present, 61 states became part of this convention by signing and accepting its conditions.

\section{Cooperation to diminish internationl criminality}

Criminality has no frontiers. Criminals act regardless existing cinventional borders . Lately overborders criminality increased both in to greater number of participantsin an organized form as well as in its diversity forms starting from minor criminality and climbing to its most powerfull organizing form- human traffic and terrorism.

As an answer to this phenomenom, the police institutions founded the so-called " Internal Attached" which cames to complete the activity of the existing traditional international institutions such as the Interpol and Europol. [8]

The Internal Attached offices founded for he first time in 2002 constitute the modality of achieving the external represenation of the Minstry of Internal Affaires. By means of this institution, international police cooperation gets more successful in a direct bilateral plan. The internal affairs attached office founded within a Romanian diplomatic mission abroaded has got the following members: internal affaires attached, internal affaires second attached 
or connecting officer as well as auxiliary staff.

By " Internal affaires attached" we mean the nominated person by order of Ministry of Internal Affaires to represent this state in the acreditating state .

By "Connecting Officer" we mean the nominated person designed by the Internal Minister to develop activities of international cooperation as well as certain types of external representation of the institution, everyhing being planned for a determinated period and in a specific specialits domain within the accepting space or nearby an international organization.

By " Auxiliary Staff" we mean staff behaing to the Ministry of Internal Affaires possessing various tehnical specialities aimed work inside the Internal Affaires attached office, in order to suport activities of international representation at abroaded positions.

The diplomatic mission which involves the attached person proves to the authorities form the acreditating state the personal dates, acreditating that he is part of the diplomatic personnel for that mission.

To exercise his duties, the internal affairs attached respects sovereignty, laws and jurisdiction of the acreditar state.

\section{Internal attached's duties}

Promotes and facilitates bilateral and multilateral cooperation into the internal affairs domain regarding offering, receiving assistance by the Romanian specialized authorities for:

- Fluent exchange of operational information necessarily to prevent and fight against criminality, maintaining and respecting public order;

- Facilitate solutions to police assistance requests as well as to the judiciary ones concerning penal matters;

- Exercise involved missions to control borders and respect foreigners' living conditions;

- Facilitate contacts and achieve collaborating objectives concerning internal affairs as written in the legal instruments dealt by the Romanian Ministry of Internal Affairs or the Romanian Government with the authorities of the accredited state;

To accomplish the mission of external representation, the internal affairs attached does the following activities:

Monitorising - the registered evolutions concerning criminality state phenomenon:

-the adopted measures to prevent and fight against it;

-the development of political, legislative, social order in the accrediting state;

-stating corresponding ways addressed to the Ministry of Internal Affairs in order to elaborate new politics or to adopt new decisions linned to all these aspects;

Participating to prepare, project and execute programmes within the logistic assistance as well as to prepare and instruct specialized staff detached by Romania in order to subscribe to the European standards and ways of practice in all domains found inside the Ministry of Internal Affairs competence;

Offering consultancy and assistance for the specialized institutions from the accrediting state concerning problems fund inside the Ministry of Internal Affairs competence;

Achieve the information exchange which is necessary to the police authorities and the Romanian border police, as well as to facilitate procedures of penal observation throughout contacts with

-authorities responsible to prevent and fight against criminality from the accredited state;

-the National Central Interpol office from the accredited state;

-internal affairs attached parsons;

-linking officers to other states;

-residents into the accredited state or other ones who cover the respective space under multiple acceptances;

-other Romanian representatives abroad; -other persons, institutions, authorities. 


\section{Conclusions}

Accord both assistance and support according to cases both having the acceptance of the Ministry of Internal Affairs, police officers, Romanian clerks being in mission in the accredited state, concerning problems focused on the police information exchanges, solving some mutual assistance requests, both police and judiciary; organizing or participating to conferences, international work reunions, mainly in the middle of specific activities aimed to the process of European integration as well as by these:

- Participating to the process of the legal and juridical assistance as well as to that of international criminals' chasing;

- Being present when suspects or witnesses are questioned, participating as an observer to their personal control or other specific questioning methods;

- Analyzing and using the found documents or those which have been given;

- Supporting, having the Ministry of Interior's acceptance, the responsible authorities in preventing and fighting against criminality in the accredited state at their requests, respecting their own procedures in penal analysis, according to the way in which all these do have any connection with Romanian citizens or other physical or juridical persons from Romania;

- Initiating, at orders, both announcing and effective participation in preparing, organizing and achieving of some over borders, operative actions;

- Supporting the process of both European and Euro Atlantic Romanian integration to aim the legislative fitting to adopt practice and standards in the justice field and the internal affairs;

- Sustaining lectures and courses or presenting information to those institutions which have obligations in the accredited space;

- Participating to conferences and specialty meetings;

- Participating as an representative of the Ministry of Internal Affairs to different ceremonies and other protecting activities from Romania;

\section{References}

[1] Valeria Mahoc definition diplomacy Explicative Romanian Dictionary

[2] Definition diplomacy - Oxford Dictionary

[3] M.I.Caragiale, C.116 Explicative Romanian Dictionary

[4] C.Petrecscu, C.V.227 [Trahanache] Explicative Romanian Dictionary 1993

[5] Explicative Romanian Dictionary 1993-2009

[6] The decision n.16/2017 regarding the Ministry of Internal Affair's organisation and functions

[7] The convention concerning diplomatic relations signed at Vienne

[8] Stefan Pop , Corneliu Alexandru , Gelu Olteanu - "Policeman or Diplomacy Representative? The Internal Affaires Attached Guide” Ed. MAI 1996. 